\title{
Efficacy of Inactivation of Human Enteroviruses by Dual-Wavelength Germicidal Ultraviolet (UV-C) Light Emitting Diodes (LEDs)
}

\author{
Hyoungmin Woo ${ }^{1}$, Sara E. Beck ${ }^{2, \dagger}$, Laura A. Boczek ${ }^{1}$, Kelsie M. Carlson ${ }^{1, \ddagger}$, \\ Nichole E. Brinkman ${ }^{1}$, Karl G. Linden ${ }^{2}{ }^{(D}$, Oliver R. Lawal ${ }^{3}$, Samuel L. Hayes ${ }^{1}$ (D) and \\ Hodon Ryu 1,* \\ 1 United States Environmental Protection Agency, Office of Research and Development, 26 W. Martin Luther \\ King Dr., Cincinnati, OH 45268, USA; hyoungmin.woo@gmail.com (H.W.); boczek.laura@epa.gov (L.A.B.); \\ Kelsie.Carlson@weasengineering.com (K.M.C.); Brinkman.Nichole@epa.gov (N.E.B.); \\ shayes936@gmail.com (S.L.H.) \\ 2 Department of Civil, Environmental, and Architectural Engineering, University of Colorado Boulder, \\ UCB 428, Boulder, CO 80309, USA; sara.beck@colorado.edu (S.E.B.); karl.linden@colorado.edu (K.G.L.) \\ 3 AquiSense Technologies, 4400 Olympic Boulevard, Erlanger, KY 41018, USA; oliver.lawal@aquisense.com \\ * Correspondence: ryu.hodon@epa.gov; Tel.: +1-513-487-2062 \\ + Present address: Department of Environmental Microbiology, Eawag: Swiss Federal Institute of Aquatic \\ Science and Technology, 8600 Dubendorf, Switzerland. \\ $\ddagger \quad$ Present address: Weas Engineering, Inc., 17297 Oak Ridge Rd, Westfield, IN 46074, USA.
}

Received: 26 April 2019; Accepted: 28 May 2019; Published: 30 May 2019

\begin{abstract}
The efficacy of germicidal ultraviolet (UV-C) light emitting diodes (LEDs) was evaluated for inactivating human enteroviruses included on the United States Environmental Protection Agency (EPA)'s Contaminant Candidate List (CCL). A UV-C LED device, emitting at peaks of $260 \mathrm{~nm}$ and $280 \mathrm{~nm}$ and the combination of 260/280 $\mathrm{nm}$ together, was used to measure and compare potential synergistic effects of dual wavelengths for disinfecting viral organisms. The $260 \mathrm{~nm}$ LED proved to be the most effective at inactivating the CCL enteroviruses tested. To obtain 2- $\log _{10}$ inactivation credit for the $260 \mathrm{~nm}$ LED, the fluences (UV doses) required are approximately $8 \mathrm{~mJ} / \mathrm{cm}^{2}$ for coxsackievirus A10 and poliovirus $1,10 \mathrm{~mJ} / \mathrm{cm}^{2}$ for enterovirus 70 , and $13 \mathrm{~mJ} / \mathrm{cm}^{2}$ for echovirus 30 . No synergistic effect was detected when evaluating the log inactivation of enteroviruses irradiated by the dual-wavelength UV-C LEDs.
\end{abstract}

Keywords: ultraviolet disinfection; dual-wavelength; UV-C LEDs; human enteroviruses; viral inactivation efficacy; synergy

\section{Introduction}

Human enteroviruses are a significant cause of waterborne disease, resulting in gastrointestinal and upper respiratory tract infections, as well as more severe illnesses, such as viral meningitis and encephalitis [1,2]. Non-polio enteroviruses cause about 10 to 15 million infections each year in the United States [3]. Enterovirus 71, as well as poliovirus, were listed in the top five global infectious disease threats determined by the Centers for Disease Control and Prevention (CDC) [4]. While most infected people with non-polio enteroviruses have mild illness, these viruses can cause infections in infants and other immunocompromised individuals with serious complications [3]. Human enteroviruses are often detected in wastewater effluents [5-7]. Since 2003, these viruses have been listed on the United States Environmental Protection Agency (USEPA)'s Contaminant Candidate 
List (CCL) as waterborne pathogens that could warrant inclusion in future regulations under the Safe Drinking Water Act [8].

Drinking water treatment plants have the disinfection capabilities to achieve effective viral inactivation through various disinfection barriers during the course of treatment processes. Unlike chemical disinfectants, such as chlorine and ozone, ultraviolet (UV) light has been successfully adapted for treating these waterborne pathogens without the formation of carcinogenic disinfection by-products (DBPs) in drinking water treatment systems [9-11]. However, conventional low-pressure (LP) mercury vapor lamps have some practical limitations in water treatment applications, such as limitations in energy efficiency and, more importantly, potential mercury contamination from accidental breakage or improper disposal of the lamps.

Emerging UV light emitting diodes (LEDs) technology has enormous potential in potable water disinfection applications. UV LEDs are well suited for point-of-use (POU) devices since LEDs are smaller, lighter, less fragile, and mercury-free [12]. Moreover, UV LEDs offer the flexibility to use preferred germicidal wavelengths, which range from 254-280 nm (i.e., germicidal ultraviolet (UV-C)) [13-19]. Extensive studies have been conducted on microorganism inactivation using UV-C LEDs [20-25]. However, most studies have focused primarily on microbial indicators and, to date, limited studies targeting waterborne pathogens have been reported. Most recently, Rattanakul and Oguma [25] showed inactivation efficacy of Pseudomonas aeruginosa and Legionella pneumophila, using UV LEDs with peak wavelength emissions at 265 and $280 \mathrm{~nm}$. Beck et al. [26] reported comprehensive results of dual-wavelength UV-C LEDs emitting at peaks of $260 \mathrm{~nm}, 280 \mathrm{~nm}$, and the combination of $260 / 280 \mathrm{~nm}$ together against a suite of waterborne microorganisms, including human adenovirus, which is one of the most resistant pathogens to UV irradiation. To our knowledge, the efficacy of inactivation of other human enteric viruses by a polychromatic light spectrum of UV-C LED has not yet been reported. The main objective of this study was to investigate the efficacy of dual-wavelength UV-C LEDs for inactivating four serotype representatives of human enterovirus species.

\section{Materials and Methods}

Representative serotypes of the four human enteric species (Enterovirus A-D) [27] were selected as test viruses, including coxsackievirus A10 (CVA10, Kowalik strain), echovirus 30 (Echo30, Bastianni strain), poliovirus 1 (PV1, Mahoney strain), and enterovirus 70 (EV70, J670/71 strain) respectively. The enteroviruses were obtained from the American Type Culture Collection (Manassas, VA, USA) and propagated in buffalo green monkey kidney (BGMK) cells, as described previously [28]. UV-exposure experiments against these enteroviruses were performed as described previously [26]. Briefly, bench-scale performance evaluation was conducted using a collimated beam (CB) apparatus with LEDs with peak emissions of $260 \mathrm{~nm}, 280 \mathrm{~nm}$, and the combination of 260/280 nm together. The incident irradiances of the CB apparatus at the center of the dish, measured at the weighted average wavelengths of the three emissions with an ILT1400 radiometer and SED240/W detector (International Light Technologies, Peabody, MA, USA), were $0.194 \mathrm{~mW} / \mathrm{cm}^{2}, 0.314 \mathrm{~mW} / \mathrm{cm}^{2}$, and $0.473 \mathrm{~mW} / \mathrm{cm}^{2}$ for the $260 \mathrm{~nm}$ LED, the $280 \mathrm{~nm}$ LED, and the combination of $260 / 280 \mathrm{~nm}$ together $(38 \%-260 \mathrm{~nm}$ and $62 \%-280 \mathrm{~nm}$ ), respectively. The applied average fluences throughout each water sample were determined according to published methods for CB tests with polychromatic sources $[26,29,30]$. Fluence calculations incorporated the incident irradiance, the UV LED emission spectra, divergence of the light, reflection off the surface of the water, non-uniformity of the light across the petri dish (petri factor of 0.87-0.93), and the water absorbance.

Triplicate CB tests were performed with mixed stocks of four viruses. Infectious virus concentrations were determined using an integrated cell culture reverse transcriptase quantitative polymerase chain reaction (ICC-RTqPCR), as described previously [31,32]. $\log _{10}$ inactivation of enteroviruses (I) is defined by Equation (1): 


$$
\mathrm{I}=-\log _{10}\left(\frac{N_{d}}{N_{0}}\right)
$$

where $N_{0}$ and $N_{d}(\mathrm{MPN} / \mathrm{mL})$ are the initial concentration and the concentration of infectious enteroviruses after a specified UV dose, respectively. The $\log _{10}$ inactivation was estimated for four human enteroviruses at four different UV fluences $\left(5 \mathrm{~mJ} / \mathrm{cm}^{2}, 10 \mathrm{~mJ} / \mathrm{cm}^{2}, 15 \mathrm{~mJ} / \mathrm{cm}^{2}\right.$, and $\left.20 \mathrm{~mJ} / \mathrm{cm}^{2}\right)$, using a dual-wavelength UV-C LED device emitting a polychromatic light spectrum with the peaks at $259.6 \mathrm{~nm}$ and $276.6 \mathrm{~nm}$. For the comparison of UV dose response of enteroviruses to low-pressure (LP) $\mathrm{UV}$ at $254 \mathrm{~nm}$, the $\log _{10}$ inactivation rates of LP UV were adapted from Ryu et al. [32].

Analysis of variance (ANOVA) tests were performed to determine if there was a significant difference in inactivation efficacy of the tested four enteroviruses among different wavelength spectra (e.g., $260 \mathrm{~nm}, 280 \mathrm{~nm}$, and $260 / 280 \mathrm{~nm}$ ). $P$ values of $<0.05$ were considered statistically significant.

\section{Results and Discussion}

The CB experiments were designed to test the effectiveness of irradiation from individual LED $260 \mathrm{~nm}$ and $280 \mathrm{~nm}$ and the simultaneous irradiation of LED 260/280 $\mathrm{nm}$ at inactivating the selected viruses. The $\log _{10}$ inactivation results after each of the irradiation scenarios (e.g., $260 \mathrm{~nm}, 280 \mathrm{~nm}$, and 260/280 $\mathrm{nm}$ ) to each of the four viruses are presented in Figure 1. The tailing for Echo30 and EV70 was observed at $15 \mathrm{~mJ} / \mathrm{cm}^{2}$ of UV fluence, possibly due to assay limitations (i.e., detection limit). To achieve a $2-\log _{10}$ reduction in infectious virus (i.e., $99 \%$ reduction) by the most effective wavelength, $260 \mathrm{~nm}$ LED, averaged UV doses were approximately $8 \mathrm{~mJ} / \mathrm{cm}^{2}$ for CVA10 and PV1, $10 \mathrm{~mJ} / \mathrm{cm}^{2}$ for EV70, and $13 \mathrm{~mJ} / \mathrm{cm}^{2}$ for Echo30 (Figure 1). In comparison, for a 2- $\log _{10}$ reduction using $280 \mathrm{~nm}$ LED, the required doses were averaged to approximately $12 \mathrm{~mJ} / \mathrm{cm}^{2}$ for CVA10 and EV70, $11 \mathrm{~mJ} / \mathrm{cm}^{2}$ for PV1, and $15 \mathrm{~mJ} / \mathrm{cm}^{2}$ for Echo30 (Figure 1), indicating that light at a wavelength of $280 \mathrm{~nm}$ was less effective for inactivating enteroviruses.

The $5 \mathrm{~mJ} / \mathrm{cm}^{2}$ of UV dose using $260 \mathrm{~nm}$ LED can provide at least 1- $\log _{10}$ inactivation of all the enteroviruses tested (Figure A1). When $280 \mathrm{~nm}$ LED was used for the same UV dose, only EV70 showed over $1-\log _{10}$ inactivation, whereas less than $1-\log _{10}$ inactivation of the other enteroviruses was achieved. EV70 at $280 \mathrm{~nm}$ light spectrum showed the best efficacy of $\log _{10}$ inactivation but significantly less inactivation efficacy than that of $260 \mathrm{~nm}$ irradiation (i.e., 1.1 vs. $1.6 \log _{10}$ reduction for $5 \mathrm{~mJ} / \mathrm{cm}^{2}$ of UV fluence, $p=0.01$ ). At $280 \mathrm{~nm}$ light spectrum, the other viruses showed relatively low performance with $\log _{10}$ reduction range of 0.5-0.8 (Figure A1). Simultaneous irradiation at 260/280 nm LED was either as effective as $260 \mathrm{~nm}$ alone (EV70, Echo30) or less effective (CVA10, PV1). In addition, all UV-C LED wavelengths were more effective than LP-UV at $254 \mathrm{~nm}$ (Figure 1), which supports previously published reports [32,33]. Gerba et al. [33] showed that a UV dose of $14 \mathrm{~mJ} / \mathrm{cm}^{2}$ to $18 \mathrm{~mJ} / \mathrm{cm}^{2}$ resulted in a $2-\log _{10}$ inactivation credit of enteric viruses, excluding adenovirus using LP mercury vapor UV lamp. These UV doses for enteric viruses tested yielded much greater inactivation rate constants than viral indicators (e.g., MS2 and Q $\beta$ bacteriophages) [25,26], suggesting that these bacteriophages could be used as conservative viral indicators in UV disinfection studies. 


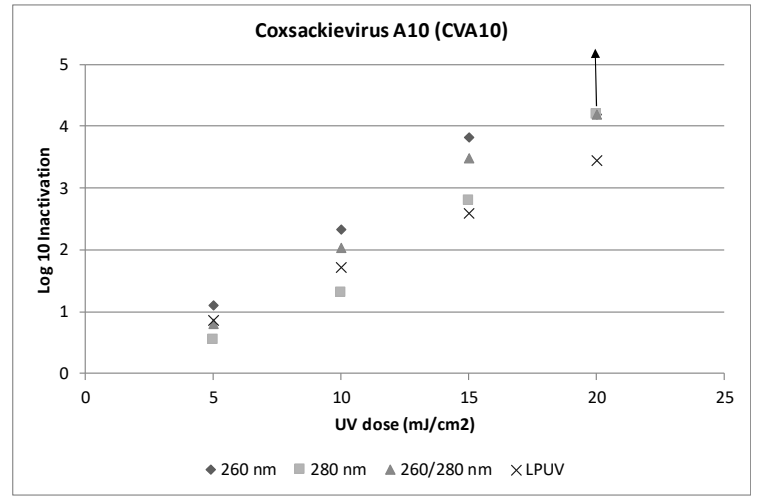

(a)

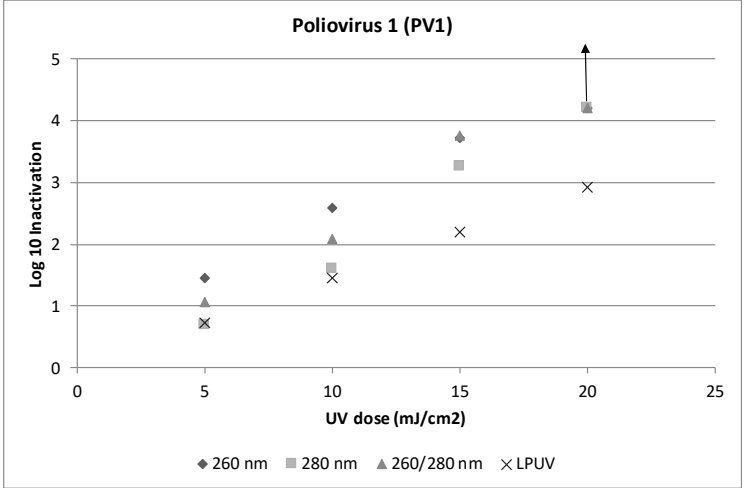

(c)

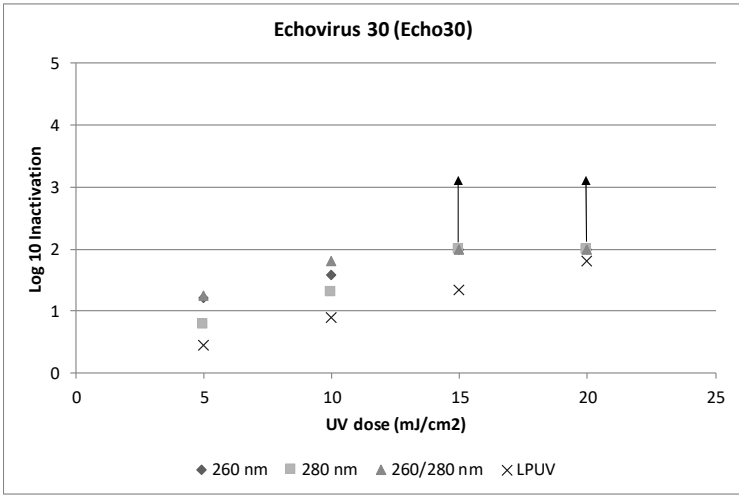

(b)

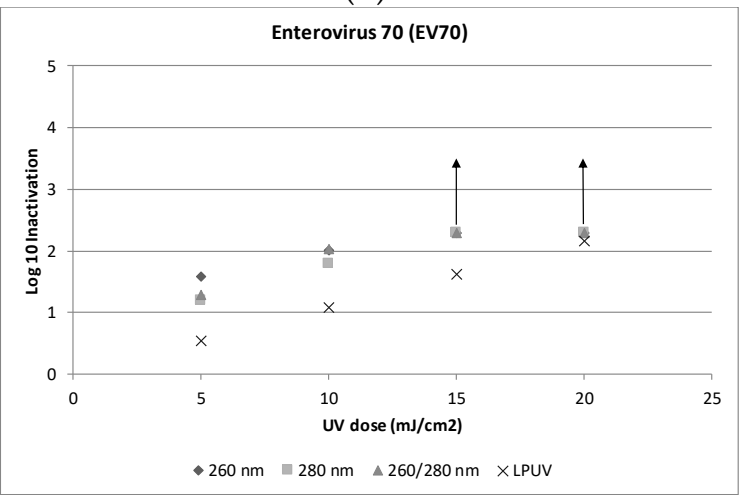

(d)

Figure 1. $\log _{10}$ inactivation of four human enteroviruses after exposure to germicidal ultraviolet light emitting diodes (UV-C LEDs) and low-pressure UV (LPUV) at $254 \mathrm{~nm}$ ((a) Coxsackievirus A10, (b) Echovirus 30, (c) Poliovirus 1, and (d) Enterovirus 70). Arrow ( $\uparrow$ ) represents detection limit. Each data point is an arithmetic average of $\log _{10}$ inactivation from independent triplicate collimated beam (CB) tests. Refer to Figure A1 for more detailed statistics, including standard deviation. The $\log _{10}$ inactivation rates LPUV at $254 \mathrm{~nm}$ were adapted from Ryu et al. [32].

Overall, the $260 \mathrm{~nm}$ light spectrum was most effective at inactivating all the enteroviruses tested, followed by the $260 / 280 \mathrm{~nm}$ light spectrum, and lastly, the $280 \mathrm{~nm}$ light spectrum (Figure 1 ). These results support our previous study with MS2 bacteriophage (an RNA virus), which also reported no synergistic inactivation of RNA viruses by the $260 / 280 \mathrm{~nm}$ combination [26]. Most recently, Rattanakul and Oguma [25] reported that $265 \mathrm{~nm}$ UV-LED was the most effective fluence for disinfecting bacterial pathogens and $Q \beta$ bacteriophage (an RNA virus) when compared to 280 and $300 \mathrm{~nm}$ UV-LEDs and LP UV at $254 \mathrm{~nm}$. Several studies have also shown that the MS2 virus is more susceptible to UV light at $260 \mathrm{~nm}$ than at $280 \mathrm{~nm}[34,35]$. A relative peak at $260 \mathrm{~nm}$ for the UV absorbance of MS2 RNA and in the MS2 action spectrum [34] indicates that this wavelength is most effective for viral RNA damage. The sufficient fluence of UV light at specific nucleic acid absorbing wavelengths inactivates microorganisms by impeding the replication of their DNA or RNA molecules $[9,36,37]$. While nucleic acids absorb UV light between 240 and $280 \mathrm{~nm}$, both DNA and RNA have peak adsorption at or near $260 \mathrm{~nm}$ [20]. Unlike conventional monochromatic UV light from a LP mercury vapor lamp (at $254 \mathrm{~nm}$ ), polychromatic UV-C LED produces a broader band of light emission. For example, an LED with a 260-nm peak emission wavelength has a spectral range of $250 \mathrm{~nm}$ to $270 \mathrm{~nm}$, which covers the peak nucleic acid adsorption range of nucleic acid molecules. However, peak absorption distribution is dependent on the specific target organism that has an absorption maximum between 254 and $280 \mathrm{~nm}[9,18]$. On the other hand, human adenovirus (a DNA virus) showed relatively high inactivation efficacy at $280 \mathrm{~nm}$ [26]. Given that the UV absorbance of protein has a relative peak near $280 \mathrm{~nm}$ [38], protein damage plays an important role in adenovirus inactivation [39]. Unlike 
human adenovirus, human enteroviruses showed less resistance to UV light of $280 \mathrm{~nm}$, suggesting a less important role of viral proteins in the infectious process. Further study on viral inactivation mechanisms across the germicidal UV spectrum is needed.

\section{Conclusions}

This research utilized a germicidal UV-C LED device emitting a polychromatic light spectrum around the peak at 260 and $280 \mathrm{~nm}$ to evaluate its efficacy at inactivating human enteroviruses in water. The comparison of $\log _{10}$ inactivation of microorganisms irradiated individually by 260 and $280 \mathrm{~nm}$ UV LED units and the $\log _{10}$ inactivation achieved from the combined 260/280 irradiation shows no synergistic effects. Irradiation of $260 \mathrm{~nm}$ peak light spectrum is more effective for the inactivation of human enteroviruses. Overall, UV LEDs showed the capability to effectively inactivate the CCL enteroviruses tested. The higher efficacy of the $260 \mathrm{~nm}$ LED encourages further studies on its applicability for sustainable water treatment and other CCL pathogens. UV-LEDs also have several practical advantages that allow for a device effective at the point of use (POU). This would disinfect drinking water prior to public consumption. As waterborne pathogens continue to pose a public health threat, the development of novel technologies—such as LED POU devices—will be important to promote safe drinking water.

Author Contributions: Conceptualization, K.G.L., O.R.L., S.L.H., and H.R.; Methodology, H.W., S.E.B., L.A.B., K.M.C., and N.E.B.; Validation, H.W. and S.E.B.; Formal Analysis, H.W. and S.E.B.; Investigation, H.W., S.E.B., L.A.B., K.M.C., and N.E.B.; Resources, K.G.L., O.R.L., and H.R.; Data Curation, H.W. and S.E.B.; Writing-Original Draft Preparation, H.W.; Writing—Review \& Editing, H.R.; Supervision, K.G.L. and H.R.; Project Administration, S.L.H. and H.R.

Funding: This research received no external funding.

Acknowledgments: We thank Jeongwon Ryu for an editorial review of this manuscript. The U.S. Environmental Protection Agency, through its Office of Research and Development, funded and managed the research described herein. This work has been subjected to the agency's administrative review and has been approved for external publication. Any opinions expressed in this paper are those of the authors and do not necessarily reflect the views of the agency; therefore, no official endorsement should be inferred. Any mention of trade names or commercial products does not constitute endorsement or recommendation for use.

Conflicts of Interest: The authors declare no conflict of interest. 


\section{Appendix A}

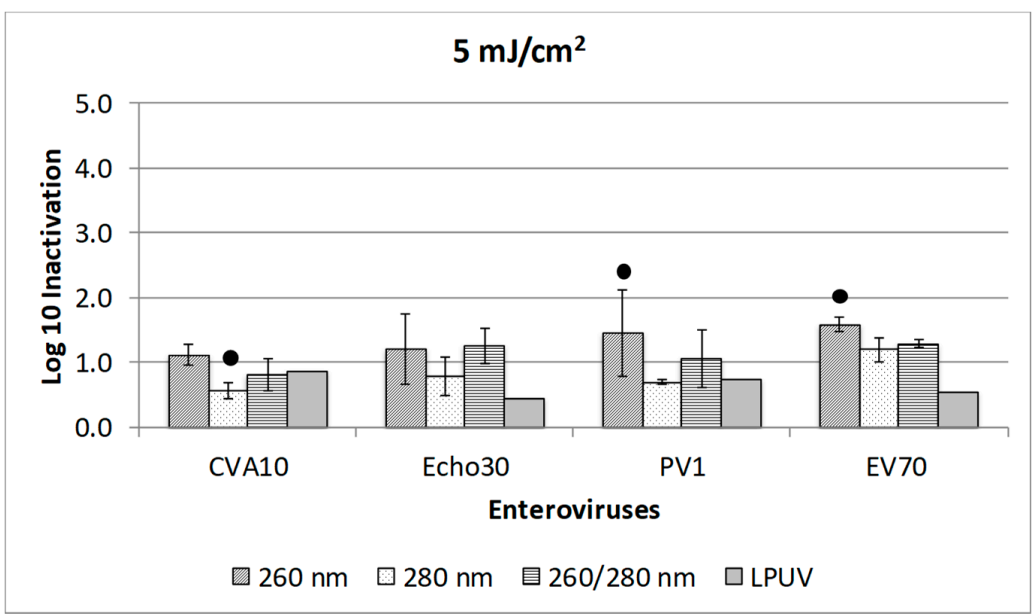

(a)

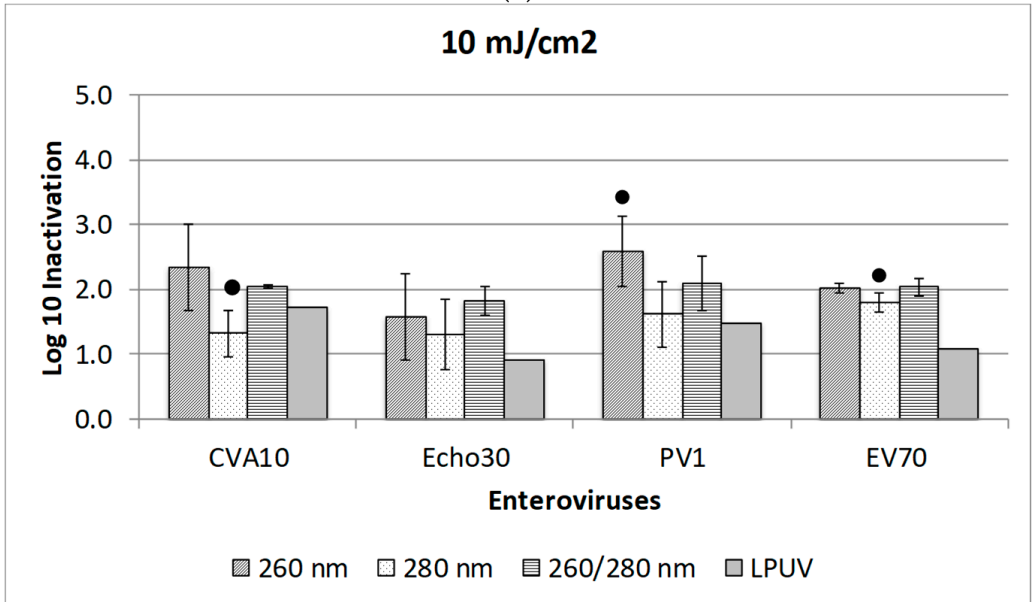

(b)

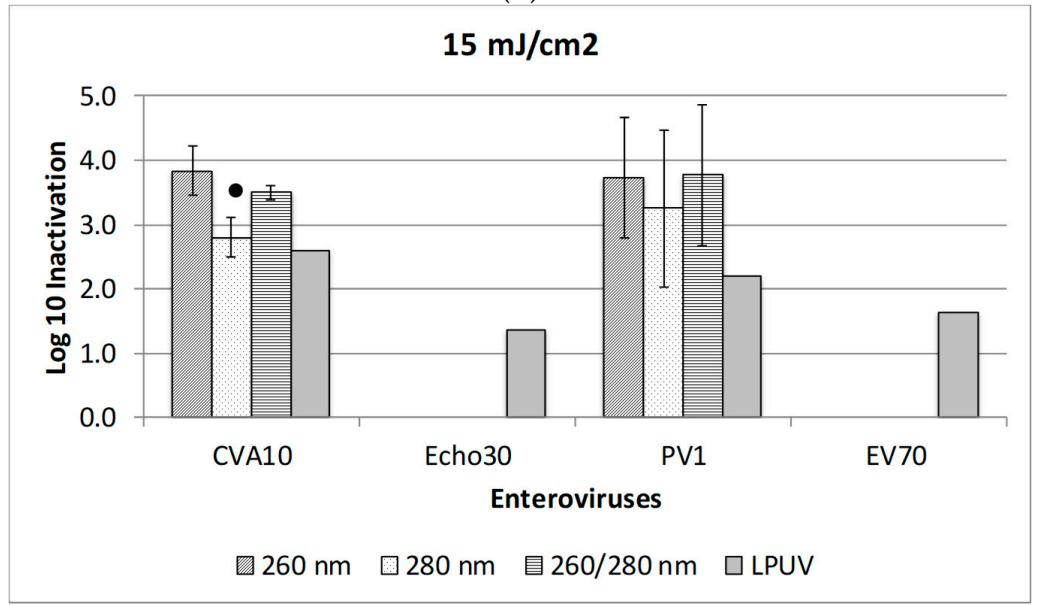

(c)

Figure A1. Comparison results of $\log _{10}$ inactivation rate from the $5 \mathrm{~mJ} / \mathrm{cm}^{2}(\mathbf{a}), 10 \mathrm{~mJ} / \mathrm{cm}^{2}(\mathbf{b})$, and $15 \mathrm{~mJ} / \mathrm{cm}^{2}$ (c) irradiation of UV-C LEDs for four human enteroviruses. The error bars represent 1 standard deviation. Symbol $(\bullet)$ represents the $p$ value of $<0.05$ among three wavelengths, as determined by ANOVA. Echo30 and EV70 for a UV dose of $15 \mathrm{~mJ} / \mathrm{cm}^{2}$ were not determined. The $\log _{10}$ inactivation rates by low-pressure UV (LPUV) at $254 \mathrm{~nm}$ were estimated using UV dose-response curves with a UV dose range of $10-30 \mathrm{~mJ} / \mathrm{cm}^{2}$, adapted from Ryu et al. [32]. 


\section{References}

1. Greninger, A.L.; Naccache, S.N.; Messacar, K.; Clayton, A.; Yu, G.; Somasekar, S.; Federman, S.; Stryke, D.; Anderson, C.; Yagi, S.; et al. A novel outbreak enterovirus D68 strain associated with acute flaccid myelitis cases in the USA (2012-14): A retrospective cohort study. Lancet Infect. Dis. 2015, 15, 671-682. [CrossRef]

2. Khan, F. Enterovirus D68: Acute respiratory illness and the 2014 outbreak. Emerg. Med. Clinucs N. Am. 2015, 33, e19-e32. [CrossRef]

3. Centers for Disease Control and Prevention. Non-Polio Enterovirus. 2018. Available online: https: //www.cdc.gov/non-polio-enterovirus/index.html (accessed on 29 May 2019).

4. Centers for Disease Control and Prevention. Global Health-Global Disease Detection and Emergency Response. 2012. Available online: https://www.cdc.gov/globalhealth/healthprotection/gdd/resources/ factsheets.html (accessed on 29 May 2019).

5. Okoh, A.I.; Sibanda, T.; Gusha, S.S. Inadequately treated wastewater as a source of human enteric viruses in the environment. Int. J. Environ. Res. Public Health 2010, 7, 2620-2637. [CrossRef] [PubMed]

6. Hewitt, J.; Leonard, M.; Greening, G.; Lewis, G. Influence of wastewater treatment process and the population size on human virus profiles in wastewater. Water Res. 2011, 45, 6267-6276. [CrossRef]

7. Brinkman, N.E.; Fout, G.S.; Keely, S.P. Retrospective surveillance of wastewater to examine seasonal dynamics of enterovirus infections. mSphere 2017, 2, e00099-17. [CrossRef] [PubMed]

8. United States Environmental Protection Agency. Drinking Water Contaminant Candidate List 4-Final. 2016. Available online: https://www.epa.gov/ccl/chemical-contaminants-ccl-4 (accessed on 29 May 2019).

9. Bolton, J.R.; Cotton, C.A. The Ultraviolet Disinfection Handbook; American Water Works Association: Denver, CO, USA, 2008; ISBN 9781583215845.

10. Hijnen, W.A.; Beerendonk, E.F.; Medema, G.J. Inactivation credit of UV radiation for viruses, bacteria and protozoan (oo)cysts in water: A review. Water Res. 2006, 40, 3-22. [CrossRef]

11. Reckhow, D.A.; Linden, K.G.; Kim, J.; Shemer, H.; Makdissy, G. Effect of UV treatment on DBP formation. J. Am. Water Works Assoc. 2010, 102, 100-113. [CrossRef]

12. Lui, G.Y.; Roser, D.; Corkish, R.; Ashbolt, N.J.; Stuetz, R. Point-of-use water disinfection using ultraviolet and visible light-emitting diodes. Sci. Total Environ. 2016, 553, 626-635. [CrossRef] [PubMed]

13. Vilhunen, S.; Särkkä, H.; Sillanpää, M. Ultraviolet light-emitting diodes in water disinfection. Environ. Sci. Pollut. Res. 2009, 16, 439-442. [CrossRef]

14. Chatterley, C.; Linden, K. Demonstration and evaluation of germicidal UV-LEDs for point-of-use water disinfection. J. Water Health 2010, 8, 479-486. [CrossRef] [PubMed]

15. Eischeid, A.C.; Linden, K.G. Molecular Indications of Protein Damage in Adenoviruses after UV Disinfection. Appl. Environ. Microbiol. 2010, 77, 1145-1147. [CrossRef] [PubMed]

16. Würtele, M.A.; Kolbe, T.; Lipsz, M.; Külberg, A.; Weyers, M.; Kneissl, M.; Jekel, M. Application of GaN-based ultraviolet-C light emitting diodes-UV LEDs-For water disinfection. Water Res. 2011, 45, 1481-1489. [CrossRef]

17. Oguma, K.; Kita, R.; Sakai, H.; Murakami, M.; Takizawa, S. Application of UV light emitting diodes to batch and flow-through water disinfection systems. Desalination 2013, 328, 24-30. [CrossRef]

18. Beck, S.E.; Rodriguez, R.A.; Linden, K.G.; Hargy, T.M.; Larason, T.C.; Wright, H.B. Wavelength dependent UV inactivation and DNA damage of adenovirus as measured by cell culture infectivity and long range quantitative PCR. Environ. Sci. Technol. 2014, 48, 591-598. [CrossRef] [PubMed]

19. Chen, J.; Loeb, S.; Kim, J.-H. LED revolution: Fundamentals and prospects for UV disinfection applications. Environ. Sci. Water Res. Technol. 2017, 3, 188-202. [CrossRef]

20. Chen, R.Z.; Craik, S.A.; Bolton, J.R. Comparison of the action spectra and relative DNA absorbance spectra of microorganisms: Information important for the determination of germicidal fluence (UV dose) in an ultraviolet disinfection of water. Water Res. 2009, 43, 5087-5096. [CrossRef] [PubMed]

21. Bowker, C.; Sain, A.; Shatalov, M.; Ducoste, J. Microbial UV fluence-response assessment using a novel UV-LED collimated beam system. Water Res. 2011, 45, 2011-2019. [CrossRef] [PubMed]

22. Chevremont, A.C.; Farnet, A.M.; Coulomb, B.; Boudenne, J.L. Effect of coupled UV-A and UV-C LEDs on both microbiological and chemical pollution of urban wastewaters. Sci. Total Environ. 2012, 426, 304-310. [CrossRef] [PubMed] 
23. Oguma, K.; Rattanakul, S.; Bolton, J.R. Application of UV light-emitting diodes to adenovirus in water. J. Environ. Eng. 2016, 142, 04015082. [CrossRef]

24. Song, K.; Mohseni, M.; Taghipour, F. Application of ultraviolet light-emitting diodes (UV-LEDs) for water disinfection: A review. Water Res. 2016, 94, 341-349. [CrossRef] [PubMed]

25. Rattanakul, S.; Oguma, K. Inactivation kinetics and efficiencies of UV-LEDs against Pseudomonas aeruginosa, Legionella pneumophila, and surrogate microorganisms. Water Res. 2018, 130, 31-37. [CrossRef]

26. Beck, S.E.; Ryu, H.; Boczek, L.A.; Cashdollar, J.L.; Jeanis, K.M.; Rosenblum, J.S.; Lawal, O.R.; Linden, K.G. Evaluating UV-C LED disinfection performance and investigating potential dual-wavelength synergy. Water Res. 2017, 109, 207-216. [CrossRef]

27. ICTV (International Committee on Taxonomy of Viruses). Virus Taxonomy: The Classification and Nomenclature of Viruses, the Online (10th) Report of the ICTV-Master Species Lists. 2017. Available online: https://talk.ictvonline.org/ictv-reports/ictv_online_report (accessed on 29 May 2019).

28. Dahling, D.R.; Wright, B.A. Optimization of the BGM cell line culture and viral assay procedures for monitoring viruses in the environment. Appl. Environ. Microbiol. 1986, 51, 790-812. [PubMed]

29. Bolton, J.R.; Linden, K.G.L. Standardization of methods for fluence (UV dose) determination in bench-scale uv experiments. J. Environ. Eng. 2003, 129, 209-215. [CrossRef]

30. Linden, K.G.; Darby, J.L. Estimating effective germicidal dose from medium-pressure UV lamps. J. Environ. Eng. 1997, 123, 1142-1149. [CrossRef]

31. Mayer, B.K.; Ryu, H.; Gerrity, D.; Abbaszadegan, M. Development and validation of an integrated cell culture-qRTPCR assay for simultaneous quantification of coxsackieviruses, echoviruses, and polioviruses in disinfection studies. Water Sci. Technol. 2010, 61, 375-387. [CrossRef]

32. Ryu, H.; Schrantz, K.A.; Brinkman, N.E.; Boczek, L.A. Applicability of integrated cell culture reverse transcriptase quantitative PCR (ICC-RTqPCR) for the simultaneous detection of the four human enteric enterovirus species in disinfection studies. J. Virol. Methods 2018, 258, 35-40. [CrossRef] [PubMed]

33. Gerba, C.P.; Gramos, D.M.; Nwachuku, N. Comparative inactivation of enteroviruses and adenovirus 2 by UV light. Appl. Environ. Microbiol. 2002, 68, 5167-5169. [CrossRef]

34. Mamane-Gravetz, H.; Linden, K.G.; Cabaj, A.; Sommer, R. Spectral sensitivity of Bacillus subtilis spores and MS2 coliphage for validation testing of ultraviolet reactors for water disinfection. Environ. Sci. Technol. 2005, 39, 7845-7852. [CrossRef] [PubMed]

35. Beck, S.E.; Rodriguez, R.A.; Hawkins, M.A.; Hargy, T.M.; Larason, T.C.; Linden, K.G. Comparison of UV-induced inactivation and RNA damage in MS2 phage across the germicidal UV spectrum. Appl. Environ. Microbiol. 2016, 82, 1468-1474. [CrossRef]

36. Gates, F.L. A study of the bactericidal action of ultra violet light: III. the absorption of ultra violet light by bacteria. J. Gen. Physiol. 1930, 14, 31-42. [CrossRef]

37. Eischeid, A.C.; Meyer, J.N.; Linden, K.G. UV disinfection of adenoviruses: Molecular indications of DNA damage efficiency. Appl. Environ. Microbiol. 2009, 75, 23-28. [CrossRef]

38. Harm, W. Biological Effects of Ultraviolet Radiation; Cambridge University Press: Cambridge, UK, 1980.

39. Beck, S.E.; Hull, N.M.; Poepping, C.; Linden, K.G. Wavelength-Dependent Damage to Adenoviral Proteins Across the Germicidal UV Spectrum. Environ. Sci. Technol. 2018, 52, 223-229. [CrossRef]

(C) 2019 by the authors. Licensee MDPI, Basel, Switzerland. This article is an open access article distributed under the terms and conditions of the Creative Commons Attribution (CC BY) license (http://creativecommons.org/licenses/by/4.0/). 